\title{
Cytokines with Possible Clinical Utility
}

\author{
R. Mertelsmann ${ }^{1}$, J. Kolitz ${ }^{2}$, K. Welte ${ }^{2}$, and F. Herrmann ${ }^{1}$
}

\section{A. Introduction}

Biological response modifiers (BRM) are agents aimed at reducing tumor growth, not primarily by exerting direct cytotoxic effects but by modulation of tumor gene expression (e.g., induction of differentiation) or by enhancing host defense mechanisms directed against cancer cells. BRM as primary therapy or as adjuncts to cytotoxic agents in the treatment of cancers have attracted increasing interest in view of stagnating clinical results in many areas [1], and there is increasing evidence of in vitro and in vivo efficacy of these agents. Furthermore, advances in molecular biology suggesting that oncogenes and their products play a crucial role in oncogenesis support approaches to modulation of regulatory mechanisms as a means of controlling tumor cell growth.

${ }^{1}$ Department of Hematology, University of Mainz, Mainz, Federal Republic of Germany

${ }^{2}$ Laboratory of Cytokine Biology, Sloan-Kettering Institute, New York, NY, USA
Clinical trials of BRM are more complex than those evaluating cytotoxic agents which are generally given at maximum tolerated dosages. Maximum tolerated doses of BRM are not necessarily optimal for modifying biological response, nor are they always the most efficacious doses. A tentative classification for BRM with some representative agents is presented in Table 1.

Agents such as retinoic acid affect tumor cell proliferation and differentiation, apparently through modulation of tumor cell gene expression rather than through host mechanisms. It should be kept in mind, however, that tumor-host interactions are subject to an intricate regulatory network of cells and cytokines, similar to the endocrine system. Modulation of one parameter could have additional, indirect effects on the biological response network. Table 2 describes cytokines that have been cloned and have thus been identified as unique gene products.

It has now become increasingly clear that the original hypothesis of "one producer cell type - one cytokine - one target cell type" does not reflect the biological facts. Ample

Table 1. Biological response modifiers

\begin{tabular}{ll}
\hline Group & Examples \\
\hline 1. Monoclonal antibodies & Anti-melanoma, anti-T cell \\
2. Cytokines & IL1, 2, 3; IFN $\alpha, \beta, \gamma ;$ TNF $\alpha, \beta ;$ G-, g/M0-, M0-CSF, EPO, EPA \\
3. Synthetic agents & retinoid acid, vitamin D3, HMBA \\
4. Immunoregulatory peptides & Tuftsin, endorphins
\end{tabular}

$I L 1,2,3$; Interleukin $1,2,3 ; I F N \alpha, \beta, \gamma$, interferon $\alpha, \beta, \gamma ; T N F \alpha, \beta$, tumor necrosis factor $\alpha, \beta$; $C S F$ for $G, G / M O, M$, colony stimulating factors for granulocytes, granulocytes/macrophages, macrophages; $E P O$, erythropoietin; $E P A$, erythroid potentiating activity; $H M B A$, hexamethylene bisacetamide 
$\varnothing \quad$ Table 2. Recombinant human cytokines

\begin{tabular}{|c|c|c|c|c|c|}
\hline Agent & Receptor & $\begin{array}{l}\text { Hemopoietic } \\
\text { producer cell }\end{array}$ & cDNA cloning reported by & Growth factor for & Activation factor for \\
\hline IL 1 & $-^{a}$ & Mo & March et al. (1985) Nature 315:641 & $\mathrm{T}, \mathrm{B}$ & $\mathrm{T}, \mathrm{B}$ \\
\hline IL 2 & Tac & $\mathrm{T}$ & Taniguchi et al. (1983) Nature 302:305 & $\mathrm{T}, \mathrm{NK}, \mathrm{B}, \mathrm{M} 0^{\mathrm{c}}$ & $\mathrm{T}^{\mathrm{c}}, \mathrm{NK}^{\mathrm{c}}, \mathrm{B}, \mathrm{MO}^{\mathrm{c}}$ \\
\hline IL 3 & - & $\mathrm{T}$ & Not published & G/M0-PC, early RBC-PC & $\mathrm{nd}^{\mathrm{d}}$ \\
\hline IFN $\alpha$ & - & $\mathrm{B}, \mathrm{MO}, \mathrm{Nk}$ & Goeddel et al. (1980) Nature 287:411 & - & $\mathrm{NK}^{\mathrm{c}}$ \\
\hline IFN $\beta$ & - & - & Derynck et al. (1980) Nature 285:542 & - & - \\
\hline IFN $\gamma$ & - & $\mathrm{T}, \mathrm{NK}$ & Gray et al. (1981) Nature 295:503 & - & $\mathrm{NK}, \mathrm{MO}^{\mathrm{c}}$ \\
\hline $\mathrm{TNF} \alpha$ & - & MO & Shirai et al. (1985) Nature $312: 803$ & $\mathrm{~T}(?)$ & $\mathrm{MO}^{\mathrm{c}}$ \\
\hline TNF $\beta$ & - & $\mathbf{T}$ & Gray et al. (1984) Nature 312:721 & nd & $\mathrm{T}$ \\
\hline G-CSF & - & Mo & Souza et al. (1986) Science 232:61 & $\mathrm{G}-\mathrm{PC}$ & $\mathrm{G}$ \\
\hline GM-CSF & fes $(?)^{e}$ & $\mathrm{~T}$ & Wong et al. (1985) Science 228:810 & G/M0-PC, early RBC-PC & Mo \\
\hline M-CSF & fms & M0 & Kawasaki et al. (1985) Science 230:291 & - & M0 \\
\hline EPO & - & - & $\begin{array}{l}\text { Lin et al. (1985) Proc Natl Acad Sci } \\
\text { USA 82:7580 }\end{array}$ & late $\mathrm{RBC}-\mathrm{PC} \mathrm{c}^{\mathrm{c}}$ & - \\
\hline EPA & - & $\mathrm{T}$ & Gasson et al. (1985) Nature 315:768 & early and late RBC-PC & - \\
\hline
\end{tabular}

${ }^{a}$ Not cDNA cloned. $M O$, macrophages; $T$, T cells; $B, \mathrm{~B}$ cells; $N K$, NK cells; $G$, granulocytes; $R B C$, red blood cells; $P C$, progenitor cells.

${ }^{b}$ Documented in clinical trials.

c Not determined.

${ }^{d}$ Related oncogene. 
evidence has been accummulated demonstrating that a given cytokine can be produced by different cell types (e.g., IL1) and can exert effects on different cell types (e.g., IL 2 on T cells, B cells, and monocytes). The biological effect appears to be dependent upon receptor density, receptor affinity, and ligand concentration, as well as on the functional state of the responder cell [2]. Since so far only one of these agents, IL2, has undergone more than preliminary clinical evaluation, the following brief review will focus on this agent.

\section{B. Interleukin 2}

The long-term proliferation of normal Tlymphocytes in suspension culture was first achieved by Morgan et al. [3], using the Tcell-derived cytokine intially designated "Tcell growth factor" (TCGF) and later renamed interleukin 2 (IL2).

The biochemical purification of IL2 and the molecular cloning and expression of its gene have led to a growing appreciation of the protean functional capabilities of this molecule. It supports the growth of human cytotoxic $T$ cells (CTL) $[4,5]$ and natural killer (NK) cells [6], it enhances the functional capabilities of NK cells $[1,8]$, and it is the factor essential for the induction and growth of human lymphokine-activated killer (LAK) cells [9]. It induces antigen-specific T-cell lines to produce B-cell growth factor-I [10], and it is capable of enhancing gammainterferon (gamma-IFN) production either alone [11] or in conjunction with mitogen [2]. An even broader immunoregulatory role for IL2 is suggested by its recently demonstrated ability to drive B cell proliferation and immunoglobulin production (13-16) and by the recent description of functionally active IL2 receptors on macrophages [12].

Not surprisingly, a number of human disease states have been found to be associated with varying defects in IL2 production and response. Among those affected are patients with primary and acquired immunodeficiency diseases, including common variable immunodeficiency (CVI) [18] and the acquired immunodeficiency syndrome (AIDS) $[19,20]$, bone marrow transplant recipients [21], and patients with severe burns and hemophilia [22] (K. Welte, unpublished observations). Furthermore, several immunosuppressive drugs appear to exert their effects by blocking IL2 gene expression [23, 24]. Defects in lectin- and mitogen-induced $T$-cell proliferation are frequently reversible in vitro by exogenous IL2. These observations, coupled with the demonstrated ability of IL2 to enhance the cytotoxicity of NK and LAK cells, have provided a rationale for clinical evaluation of IL2 in human malignancy and immunodeficiency.

The human IL2 gene has been cloned and sequenced [25], and its position on chromosome 4 has been determined by us and others $[26,27]$. Several recombinant IL2 (rIL2) preparations (Cetus, Amgen, Biogen) have been compared in our laboratory with human purified IL2 (hpIL2) and, except for higher background mitogenic activity on the part of rIL2, no differences were detected in a variety of human in vitro and murine in vitro and in vivo systems (K. Welte, V. J. Merluzzi, unpublished observations).

\section{IL2 in the Treatment of Cancer}

The ability of IL2 to restore T cell functional defects in vivo and in vitro and to induce and enhance cytoxicity against fresh and cultured tumor targets led to early exploration of its potential as an agent in the treatment of cancer. The anti-tumor activity of IL 2 has been most clearly demonstrated in conjunction with the infusion of specific immune cultured T cells or nonspecific LAK cells.

B6 mice with syngeneic Friend virus-induced FBL-3 leukemia are cured with the combination of noncurative doses of cyclophosphamide and administration of tumorimmune congeneic lymphocytes cultured in vitro and expanded in vivo with IL2 [28]. High doses of IL2 and infusions of autologous LAK cells cause major regressions of murine transplantable sarcomas and melanomas [29], with IL2 inducing in vivo proliferation of the adoptively transferred cells [30]. IL2 alone causes major regressions of murine sarcomas when given in extremely high doses (400000 U intraperitoneally every $8 \mathrm{~h}$ ) [31].

Following i.v. bolus administration of Jurkat hpIL2, the serum half-life of IL2 in 
man was 5-7 min, with a second component of clearance of 30-120 min [32]. Such a twocompartment model is compatible with our own observations following treatment of 30 patients with rIL2 (Cetus) given by 6 hour continuous i.v. infusion [35].

We completed an initial trial of hpIL2 in human malignancy and immunodeficiency at Memorial Hospital in 1983 [33]. The IL2 was purified from human PBL-conditioned medium in our laboratory [34]. The s.c. route of administration was chosen in order to achieve maximal lymphatic drainage. Escalating doses were given, to a maximum daily dose of $20000 \mathrm{U} / \mathrm{m}^{2}$ and a maximum total dose of $855000 \mathrm{U} / \mathrm{m}^{2}$, administered over 77 days.

Sixteen patients with malignancy and AIDS were treated. Except for occasional skin irritation at the injection site, no toxicity was observed. One patient, a child with probable Nezelof's syndrome who died of infectious complications after 5 days of therapy with IL2 and after an unsuccessful Tcell-depleted bone marrow graft from a haplotype-identical half brother, was found at autopsy to have all lymph nodes lymphocyte depleted, except for inguinal nodes proximal to s.c. IL2 injection sites, where lymphoid follicles were noted. This was an early suggestion of the in vivo biological activity of IL2.

While there was some suggestion of improved responsiveness to OKT3-inducible $T$-cell activation in the only two patients receiving treatment for at least 50 days, there was no clear evidence for significant biological response modification in this trial.

A trial of Jurkat hpIL2 in human malignancy has been completed at the National Cancer Institute [32]. Twelve patients with a range of solid tumors received IL2 at doses of up to $2000 \mu \mathrm{g}$ by i.v. bolus or continuous infusion weekly for 4 weeks. Biological observations included an acute decrease in peripheral blood $\mathrm{T}$ cells, affecting all major $\mathrm{T}$ cell subsets, and an increase in circulating cells capable of responding to IL2 and expressing LAK activity. No clinical response was seen. Toxicity consisted primarily of fever, chills, malaise, and reversible hepatopathy.

In a recently completed clinical trial, we administered rIL2 (Cetus) as a continuous 6- $\mathrm{h}$ i.v. infusion to 17 patients with advanced malignancy and to 13 patients with AIDS [35]. The maximum tolerated dose was $1000000 \mathrm{U} / \mathrm{m}^{2}$, with dose-limiting toxicity consisting of fever $>40^{\circ} \mathrm{C}$, thrombocytopenia, and diarrhea at the $2000000 \mathrm{U} / \mathrm{m}^{2}$ dose level. Except for one patient with a myelodysplastic syndrome, who had a fall in marrow blasts from $>10 \%$ to $1 \%$ over a 2 month period, no significant clinical responses were seen. Dose-dependent biological response-modifying effects were observed, however.

At the higher dose levels a reproducible lymphocytosis occurred, peaking on day 15 of each treatment cycle, with an up to fivefold increase in the absolute lymphocyte count. The expansion consisted of a polyclonal increase in all $\mathrm{T}$-cell subsets, with no substantive change observed in any T-cell marker or in the $\mathrm{T} 4 / \mathrm{T} 8$ ratio.

Twenty patients with solid tumors were treated with rIL2 (Cetus) at the National Cancer Institute [36] using i.v. bolus administration. No clinical responses were seen, but a Tac + lymphocytosis was also observed, along with induction of detectable gamma-interferon serum levels.

Much interest has recently been generated by the report of major tumor regressions in patients with solid tumors (primarily melanoma, colon carcinoma, and hypernephroma) treated with infusions of autologous LAK cells and high doses $(100000 \mathrm{U} /$ $\mathrm{kg}$ every $8 \mathrm{~h} \mathrm{i.v.)} \mathrm{of} \mathrm{rIL2} \mathrm{[37].} \mathrm{A} \mathrm{major} \mathrm{focus}$ of research activity will be to reduce the considerable toxicity of this approach, which has included marked fluid retention, pulmonary edema, hypotension, and reversible renal dysfunction. Whether the therapeutic effect is due primarily to the infusions of LAK cells or to the high doses of rIL2 is also presently unclear.

Given the ability of IL2 to induce LAK cells with wide anti-tumor efficacy both in vivo and in vitro and the clear demonstration of potent biological effects achievable in treated patients, additional efforts will have to be made to translate the promise of this lymphokine into clinically meaningful results. Subcutaneous, i.p., (P. Chapman et al., submitted) and intralesional administration might achieve sufficiently high local concentration of IL2 to generate LAK cells in vivo 
with acceptable toxicity. The use of cyclophosphamide in low doses directed against suppressor $\mathrm{T}$ cells is a potential means of countering regulatory mechanisms limiting the efficacy of IL2 (J. Kolitz, manuscript in preparation). Defining the phenotype and optimizing the activation conditions for LAK cells may lead to therapies with reduced toxicities. The use of monoclonal antibodies directed against tumor antigens might lead to local inflammatory infiltrates in tumor sites [38]. CTL numbers and NK/ LAK cytotoxicity could then possibly be amplified in vivo by IL2. These approaches are being utilized in current or planned clinical trials at Memorial Hospital, New York, and at the Department of Hematology of the University of Mainz.

\section{References}

1. Bailar JC, Smith EM (1986) Progress against cancer? N Engl J Med 314:1226-1232

2. Herrmann F, Cannistra SA, Griffin JD (1986) $T$ cell-monocyte interactions in the production of humoral factors regulating human granulopoiesis in vitro. J Immunol 136:28562862

3. Morgan DA, Ruscetti FW, Gallo RC (1976) Selective in vitro growth of T-lymphocytes from normal human bone marrows. Science 193:1007-1008

4. Gillis S, Smith KA (1977) Long-term culture of tumor-specific cytotoxic $\mathrm{T}$ cells. Nature 268:154-156

5. Gillis S, Baker PE, Ruscetti FW, et al. (1978) A long-term culture of human antigen-specific cytotoxic $T$ cell lines. $J$ Exp Med 148:1093-1098

6. Flomenberg N, Welte $\mathrm{K}$, Mertelsmann R, et al. (1983) Interleukin 2-dependent natural killer (NK) cell lines from patients with primary $\mathrm{T}$ cell immunodeficiencies. J Immunol 130:2635-2643

7. Henney CS, Kuribayashi K, Kern DE, et al. (1981) Interleukin 2 augments natural killer cell activity. Nature 291:335-338

8. Trinchieri G, Matsumoto-Kobayshi M, Clark SC, et al. (1984) Response of resting peripheral blood natural killer cells to interleukin 2. J Exp Med 160:1147-1169

9. Grimm EA, Mazumder A, Zhang HZ, et al. (1982) Lymphokine-activated killer cell phenomenon: lysis of natural killer-resistant fresh solid tumor cells by interleukin 2 activated autologous peripheral blood lymphocytes. J Exp Med 155:1823-1841
10. Howard M, Matis L, Malck TR, et al. (1983) Interleukin 2 induces antigen-reactive $T$ cell lines to secrete BCGF-1. J Exp Med 158:2024-2039

11. Kasahara T, Hooks JJ, Dougherty SF, et al. (1983) Interleukin 2 mediated immune interferon (IFN-gamma) production by human T cells and T cell subsets. J Immunol 130:17891989

12. Pearlstein KT, Palladino MA, Welte K, et al. (1983) Purified human interleukin 2 enhanced induction of immune interferon. Cell Immunol 80:1-9

13. Zubler RH, Lowenthal JW, Erard F, et al. (1984) Activated B cells express receptor for, and proliferate in response to, pure interleukin 2. J Exp Med 160:1170-1183

14. Waldmann TA, Goldman CK, Robb RJ, et al. (1984) Expression of interleukin 2 receptors on activated human B cells. J Exp Med 160:1450-1466

15. Boyd AW, Fisher DC, Fox DA, et al. (1985) Structural and functional characterization of IL-2 receptors on activated human B cells. $J$ Immunol 134:2387-2392

16. Ralph P, Jeong G, Welte K, et al. (1984) Stimulation of immunoglobulin secretion in human B-lymphocytes as a direct effect of high concentrations of IL-2. J Immunol 133:24422445

17. Herrmann F, Cannistra SA, Levine $\mathrm{H}$, et al. (1985) Expression of interleukin 2 receptors and binding of interleukin 2 by gamma interferon-induced human leukemic and normal monocytic cells. J Exp Med 162:1111-1116

18. Kruger G, Welte K, Ciobanu N, et al. (1984) Interleukin 2 correction of defective in vitro $\mathrm{T}$ cell mitogenesis in patients with common variable immunodeficiency. J Clin Immunol 4:295-303

19. Ciobanu N, Welte K, Kruger G, et al. (1983) Defective $\mathrm{T}$ cell response to PHA and mitogenic monoclonal antibodies in male homosexual with acquired immunodeficiency syndrome and its in vitro correction by interleukin 2. J Clin Immunol 3:332-340

20. Murray HW, Welte K, Jacobs JL, et al. (1985) Production of and in vitro response to interleukin 2 in the acquired immunodeficiency syndrome. J Clin Invest 76:1959-1964

21. Welte K, Ciobanu N, Moore MAS, et al. (1984) Defective interleukin 2 production in patients after bone marrow transplantation and in vitro restoration of defective T-lymphocyte proliferation by highly purified interleukin 2. Blood 64:380-385

22. Antonacci A, Calvano SE, Reaves A, et al. (1984) Autologous and allogeneic mixed lymphocyte responses following thermal injury in man: the immunomodulatory effects of inter- 
leukin 1, interleukin 2 and a prostaglandin inhibitor, WY-18251. Clin Immunol Immunopath 30:304-320

23. Kröncke M, Leonard WJ, Depper JM (1984) Cyclosporin A inhibits T-cell growth factor gene expression at the level of mRNA transcription. Proc Natl Acad Sci USA 81:5214 5218

24. Arya SK, Wong-Staal F, Gallo RC, et al. (1984) Dexamethasone-mediated inhibition of human T-cell growth factor and gamma-interferon messenger RNA. J Immunol 133:273-276

25. Holbrook NJ, Smith KA, Fornace AJ Jr, et al. (1984) T-cell growth factor: complete nucleotide sequence and organization of the gene in normal and malignant cells. Proc Natl Acad Sci USA 81:1634-1638

26. Siegal LJ, Harper ME, Wong-Staal F, et al. (1984) Gene for feline chromosome B1. Science 223:175-178

27. Sykora KW, Kolitz J, Szabo P, et al. (1984) The human IL2 gene is located on chromosome 4. Cancer Invest 2:261-265

28. Cheever MA, Greenberg PD, Fefer A (1982) Augmentation of the anti-tumor therapeutic efficacy of long-term cultured T-lymphocytes by in vivo administration of purified interleukin 2. J Exp Med 155:968-980

29. Mazumder A, Rosenberg SA (1984) Successful immunotherapy of natural killer-resistant established pulmonary melanoma metastases by the intravenous adoptive transfer of syngeneic lymphocytes activated in vitro by interleukin 2. J Exp Med 159:495-507

30. Ettinghausen SE, Lipford EH, Mule JJ, et al. (1985) Recombinant interleukin-2 stimulates in vivo proliferation of adoptively transferred lymphokine-activated killer (LAK) cells. J Immunol 135:3623-3635
31. Rosenberg SA, Mule JJ, Spiess PJ, et al. (1985) Regression of established pulmonary metastases and subcutaneous tumor mediated by the systemic administration of high-dose recombinant interleukin 2. J Exp Med 161:1169-1188

32. Lotze MT, Frana LW, Sharrow SO, et al. (1985) In vivo administration of purified human interleukin 2. Half-life and immunologic effects of the Jurkat cell line-derived interleukin 2. J Immunol 134:157-166

33. Mertelsmann R, Welte K, Sternber C, et al. (1984) Treatment of immunodeficiency with interleukin 2: initial exploration. Resp Modif 4:483-490

34. Welte $\mathrm{K}$, Wang CY, Mertelsmann R, et al. (1982) Purification of human interleukin 2 to apparent homogeneity and its molecular heterogeneity. J Exp Med 156:454-464

35. Kolitz JE, Holloway K, Welte K, et al. (1985) A multiple-dose phase-I trial of recombinant interleukin 2 in advanced malignancy. Proc Am Soc Clin Oncol 135:2865-2875

36. Lotze MT, Frana LW, Sharrow SO, et al. (1985) In vivo administration of purified human interleukin 2. II. Half-life, immunologic effects, and expansion of peripheral lymphoid cells in vivo with recombinant interleukin $2 . \mathrm{J}$ Immunol 135:2865-2875

37. Rosenberg SA, Lotze MT, Muul LM, et al. (1987) A progress report on the treatment of 157 patients with advanced cancer using lymphokine-activated killer cells and Interleukin2 or high-dose Interleukin-2 alone. N Engl J Med 316:889-897

38. Houghton AN, Mintzer D, Cordon-Cardo C (1985) Mouse monoclonal IgG 3 antibodydetecting GD3 ganglioside: a phase-I trial in patients with malignant melanoma. Proc Natl Acad Sci USA 82:1242-1246 